\title{
13. Amikor az alkotmány hallgat: Finnország különleges jogrendje
}

\author{
DORNFELD LÁSZLÓ
}

\section{A különleges jogrend alkotmányos és törvényi szintű szabályozása, illetve esetkörei}

Finnország azon országok körébe tartozik, ahol az alkotmány ${ }^{1}$ semmilyen rendelkezést nem tartalmaz a különleges jogrend esetköreivel kapcsolatosan. Az alkotmány kizárólag egy 2011-es módosítással elfogadott rendelkezésben tesz említést a különleges jogrendről, az alapjogok védelmének kontextusában. ${ }^{2}$ Ez kimondja, hogy az alapjogok ideiglenesen korlátozhatók - a nemzetközi jogi kötelezettségekkel összhangban -, amennyiben az országot támadás éri, vagy bármilyen más komoly veszélyt jelentő helyzet esetén. Ekkor törvényben vagy kormányrendeletben, külön törvény felhatalmazása alapján, pontosan körülírt alkalmazási körre figyelemmel lehetséges az alapjogok korlátozása.

Ez a megfogalmazás igen összetett, és a rövidsége ellenére számos lényegi elem derül ki belőle. Az alapjogok két esetben korlátozhatók: külső támadás, illetve külön törvényben

I Finnország alkotmánya (Suomen perustuslaki 11.6.1999/731) (a továbbiakban: alkotmány). Az 1999-ben elfogadott alkotmány Európa egyik legfiatalabbjának számít.

2 Alkotmány 23. szakasz.

Dr. Dornfeld László

laszlo.dornfeld@mfi.gov.hu

kutató (Mádl Ferenc Összehasonlító Jogi Intézet)

Dornfeld, L. (2021) 'Amikor az alkotmány hallgat: Finnország különleges jogrendje’ in Nagy, Z., Horváth, A. (szerk.) A különleges jogrend és nemzeti szabályozási modelljei, 301-321. o. Budapest: Mádl Ferenc Összehasonlító Jogi Intézet.

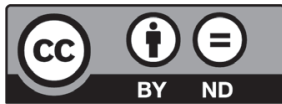


meghatározott vészhelyzet esetén. Az ideiglenes korlátozó intézkedéseket a parlament hagyja jóvá egyszerú többséggel, ugyanakkor a parlament törvényben átruházhatja a kormányra a jogot, hogy meghatározott témakörökben kormányrendelettel korlátozzon alapjogokat. Ezeknek a rendelkezéseknek meg kell felelniük az ország nemzetközi jogi kötelezettségeinek. A parlament múkködése folyamatos kell legyen a különleges jogrendi állapot idején, de a rendes jogalkotás helyett csak vétójoggal. ${ }^{3}$

A különleges jogrenddel kapcsolatos finn megoldás két jogi sajátossággal is bír. Először is, az alkotmányban megjelölt külön törvény megalkotása és jogi státusza. Az alkotmány ugyanis lehetôvé teszi az úgynevezett kivételes jogalkotást, amely az alkotmány rendes jogrendi szabályaitól való korlátozott eltérésre ad lehetőséget. ${ }^{4}$ Ezek a jogszabályok a gyakorlatban felülírják az alkotmány rendelkezéseit, anélkül, hogy az alkotmányt magát módosítani kéne, és ugyanolyan eljárásrendben kerülnek elfogadásra, mint az alkotmánymódosítások. ${ }^{5}$ A témánk szempontjából egyik leglényegesebb törvény, a 2011-ben elfogadott vészhelyzeti hatáskörökről szóló törvény ${ }^{6}$ azonban jócskán túllép ezen a határon. A másik igen érdekes megoldás, hogy az alapjogokat korlátozó egyes kormányrendeleteket külön is jóvá kell hagynia a parlamentnek, mielőtt azok hatályba léphetnek.?

A Vészhelyzeti tv. nem nevesíti a különleges jogrend általa szabályozott formáját, kizárólag kivételes körülményekről (poikkeusolojen) tesz említést, amelyek okot adnak a kormány számára a különleges jogkörök gyakorlására. A nemzetközi szakirodalom, ${ }^{8}$ illetve a finn kormány angol nyelvú kommunikációja9 egységesen szükségállapotként hivatkozik erre az állapotra, így az egyszerűség kedvéért a fejezetben is így említjük.

A másik fontos törvény a külső fegyveres támadás esetén alkalmazandó honvédelmi törvény. ${ }^{10} \mathrm{Ez}$ a törvény teremt lehetőséget a védelmi állapot (puolustustila) bevezetésére. ${ }^{11}$ Ezek alapján a finn jogrendben a különleges jogrend két formája, a szükségállapot (kivételes körülmények) és a védelmi állapot különböztethetô meg.

A szükségállapot alkalmazására a Vészhelyzeti tv. szerinti kivételes körülmények fennállása esetén van lehetőség, aminek célja a lakosság védelme, megélhetésének és gazdasági életének megőrzése, a rend és az alapvető emberi jogok fenntartása, valamint az állam területi integritásának és függetlenségének megőrzése. ${ }^{12} \mathrm{~A}$ kivételes körülmények a követ-

3 Scheinin, 2020.

4 Alkotmány 73. szakasz.

5 Ojanen, 2007, 207. o.; Cornell-Salminen, 2018, 237. o.

6 Valmiuslaki 2011/1552 (a továbbiakban: Vészhelyzeti tv.).

7 Alkotmány 23. szakasz.

8 A legtöbb helyen az ennek megfelelő state of emergency angol fogalmat használják (Cornell-Salminen, 2018; Husa, 2011; Scheinin, 2020).

9 Elérhető: https://valtioneuvosto.fi/en/-//10616/hallitus-totesi-suomen-olevan-poikkeusoloissa-koronavirustilanteen-vuoksi (Letöltve: 2020. december 15.).

10 Puolustustilalaki 22.7.1991/1083 (a továbbiakban: Honvédelmi tv.).

11 A hadiállapot megfogalmazás nem helytálló, ugyanis elrendeléséhez nem szükséges külső fegyveres konfliktus.

12 Vészhelyzeti tv. 1. szakasz. 
kezők lehetnek: fegyveres vagy hasonló támadás Finnország ellen és annak közvetlen következményei; Finnország elleni fegyveres vagy hasonló támadás jelentős veszélye; a lakosság megélhetését vagy az ország gazdaságának alapjait különösen súlyosan érintő esemény vagy veszély, amelyek jelentős kockázatot jelentenek a társadalom létfontosságú funkcióira; súlyos baleset és annak közvetlen következményei; nagyon széles körben elterjedt veszélyes fertőző betegség. ${ }^{13}$

A hatóságok a törvény szerinti hatásköreiket kivételes körülmények között is csak a cél eléréséhez szükséges ideig és a cél elérésével arányosan gyakorolhatják, amennyiben az adott helyzet az általános szabályok szerint nem kezelhetô. ${ }^{14} \mathrm{~A}$ kivételes körülmények fennállását a kormány és a köztársasági elnök együttesen állapítja meg, majd a kormány elkészíti a szükséges végrehajtó rendeleteket. Fontos, hogy magával a szükségállapot elrendelésével kapcsolatban nem szükséges a törvényhozás hozzájárulása, csak az az alapján hozott intézkedések esetén. ${ }^{15}$

A Vészhelyzeti tv. alapján a konkrét jogkorlátozó intézkedéseket tartalmazó úgynevezett végrehajtási kormányrendeletek alkothatók, kétféle eljárásban:

- általános eljárásban: a kormányrendelet legfeljebb hat hónapra adható ki, de az elfogadásától számított egy héten belül be kell nyújtani azt a finn parlamentnek; ellenkező esetben a kormányrendelet hatályát veszti. A kormányrendelet egyebekben a parlament által jóváhagyott tartalommal marad hatályban;

— sürgősséggel: a kormányrendelet legfeljebb három hónapra adható ki, és haladéktalanul be kell nyújtani azt a parlamentnek. Ha egy héten belül a parlament nem kapja meg a kormányrendeletet, az hatályát veszti.

A kivételes körülmények fennállása esetén meghozott végrehajtási kormányrendeletnek tartalmaznia kell az alkalmazni kívánt eszközöket, valamint az alkalmazás területi hatályát, amennyiben nem az ország teljes területére történik. A rendelet hatálya kormányrendelettel - egy alkalommal - legfeljebb hat hónappal meghosszabbítható, de a módosító rendeletet a parlamentnek be kell nyújtani. ${ }^{16} \mathrm{~A}$ kivételes körülmények végével a szükségállapotot meg kell szüntetni. A szükségállapot végével az összes az alapján hozott rendelkezés is hatályát veszíti. ${ }^{17}$

A Vészhelyzeti tv. II. része az egyes esetkörökre lebontva tartalmazza azon rendelkezéseket, amelyek meghozhatók. A 4. fejezet a pénzügyi piacok biztonságát érintő intézkedésekkel

13 Vészhelyzeti tv. 3. szakasz.

14 Vészhelyzeti tv. 4. szakasz.

15 Scheinin, 2020; valamint lásd a Miniszterelnöki Hivatal tájékoztatóját: https://valtioneuvosto.fi/ documents/10184/3785983/Beredskapslagen+160320.pdf/558a48cb-543d-57e6-fafe-b843ba0350e7/ Beredskapslagen+160320.pdf 2. o. (Letöltve: 2020. december 15.) „A rendkívüli körülmények fennállásának megállapításáról szóló kormányhatározat azonnal hatályba lép, és további értesítésig hatályos, és ez lehetővé teszi a végrehajtási rendelet kiadását.".

16 Vészhelyzeti tv. 6-9. szakasz.

17 Vészhelyzeti tv. 11. szakasz. 
foglalkozik, az 5. fejezet az áruk eloállításának és elosztásának, valamint az energiaellátásnak a biztosítása terén tartalmaz rendelkezéseket. A 6. fejezet az építési projektekkel, valamint az építőanyagokkal foglalkozik. A 7. fejezet a lakhatással kapcsolatosan fogalmaz meg rendelkezéseket, míg a 8. fejezet a társadalombiztosítással foglalkozik, a 9. fejezet az elektronikus információs és kommunikációs rendszerek működésének és a postai szolgáltatások elérhetősége biztosításának eszközeit tartalmazza. A 10. fejezet a közlekedés és az üzemanyag-ellátás kérdéseivel foglalkozik, a 11. fejezet a szociális és egészségügyi intézmények feladataival kapcsolatos, a 12. fejezet a költségvetési kérdésekkel, míg a 13. fejezet a munkavállalás kérdéseivel foglalkozik, a 14. fejezet pedig a munkakötelezettség kérdéseit taglalja. A 15. fejezet a kormányzati szervezet kérdéseivel, a 16. fejezet a katonai készültséggel kapcsolatos, míg a 17. szakasz a polgári védelemmel és kitelepítéssel kapcsolatos szabályozást tartalmazza.

Ez a szabályozás igen szerteágazó, és kizárólag az egyes különleges jogrendi eszközök szempontjából csoportosít. A rendelkezések túlnyomó többségének a felhatalmazottja a kormány vagy valamelyik minisztérium, valamely más központi szerv (például a nemzeti bank), esetleg a védelmi erók. A felhatalmazás alapján meghozott, a II. részbe tartozó intézkedések valamelyikét elrendelő kormányrendeletet haladéktalanul meg kell küldeni a törvényhozás számára, amely egyszerú többséggel dönt arról, hogy hatályban maradjanak-e. ${ }^{18}$ Ez a gyakorlatban azt jelenti, hogy ezeket a rendelkezéseket a parlament csak utólagosan vizsgálja felül, és már a parlament döntését megelőzően hatályba lépnek, alkalmazásukra azonban csak a parlamenti jóváhagyást követően kerülhet sor. ${ }^{19}$

A védelmi állapot bevezetése a Honvédelmi tv. értelmében akkor lehetséges, ha Finnországot támadás éri, vagy hasonló belső erőszakos zavargások az alkotmányos rend megváltoztatására irányulnak. A védelmi állapot alkalmazásának célja a függetlenség és a rend megőrzése a fenyegetéssel szemben. ${ }^{20}$ Elrendelésére a köztársasági elnök jogosult rendelettel, abban az esetben, ha a Vészhelyzeti tv. rendelkezései nem bizonyulnának elégségesnek a kialakult helyzetben. ${ }^{21}$ Akárcsak a szükségállapotnál, itt is meghatározott időre, legfeljebb három hónapra lehet dönteni a bevezetésről, amelyet a törvényhozásnak nem kell megerősíteni. Ebben az esetben is csak a különleges jogrend kapcsán hozott rendelkezések szorulnak parlamenti megerősítésre. Amenynyiben a parlament azt nem szavazza meg, vagy pedig egy héten belül nem kerül beterjesztésre a törvényhozás elé, úgy az adott rendelet hatályát veszíti. ${ }^{22}$ Amennyiben az elrendelés okai továbbra is fennállnak, a köztársasági elnök az adott végrehajtási rendeletet meghosszabbíthatja egy alkalommal, legfeljebb egy évvel. Ezt a rendelkezést a parlamentnek az eredeti határozathoz hasonlóan meg kell erősítenie. ${ }^{23}$ Amennyiben a hosszabbító rendelkezést a parlament elfogadja,

18 Vészhelyzeti tv. 10. szakasz.

19 Scheinin, 2020.

20 Honvédelmi tv. 1. szakasz.

21 Honvédelmi tv. 2. szakasz.

22 Honvédelmi tv. 3. szakasz.

23 Honvédelmi tv. 4. szakasz. 
az abban szereplő rendelkezések az eredeti három hónapos határidő letelte után is hatályban maradnak. Ha a törvényhozás még nem szavazott a kérdésben, és a lejárat elött legalább két héttel megküldésre került számukra a hosszabbításról rendelkező köztársasági elnöki rendelet, úgy a rendelkezések továbbra is hatályban maradnak a parlament döntésének megszületéséig. ${ }^{24}$ Az elrendeléshez vezetó körülmények megszúntével a védelmi állapotot elrendelő vagy meghoszszabbító köztársasági elnöki rendeletet hatályon kívül kell helyezni. A védelmi állapot megszúnését követően az az alapján hozott egyéb rendelkezések is hatályukat veszítik. ${ }^{25}$

A védelmi állapot során a Honvédelmi tv. a fokozatosság elve alapján nem zárja ki a Vészhelyzeti tv. rendelkezéseinek az alkalmazását, kivéve, ha a törvény kifejezetten kitér rá. ${ }^{26}$ Ennek megfelelően a Honvédelmi tv. már csak azon rendelkezéseket tartalmazza, amelyek a másik törvényben nem találhatók meg. A Honvédelmi tv. 2. fejezete az általános rendelkezéseket, míg a 3. fejezet a katonai és gazdasági védelem eszközeit tartalmazza. A rendelkezések felhatalmazottja az esetek többségében a kormány, valamely minisztérium, illetve a védelmi erők. A katonai hatóságok döntéshozatali jogköre szúkre szabott, amennyiben bizonyos rendelkezéseik időtartama meghaladná a két hetet, úgy a kormányzatnak kell döntenie azok fenntartásáról, és azt a hivatalos lapban is közzé kell tenni. ${ }^{27}$

\subsection{A különleges jogrendre való felkészülést segítő békeidejü szabályok és a kapcsolódó szervezetrendszer}

Finnországban régóta mûködik a felkészültségi rendszer, és az úgynevezett átfogó védelmi megközelítés évtizedek óta uralkodó nézet. Ez azt jelenti, hogy a társadalom egésze, a közigazgatás, a magánszektor és a polgárok együttesen biztosítják, hogy bármilyen helyzetben múködőképes maradjon a társadalom. Ez a fajta megközelítés megteremtette az alapot az állami és a magánszektor felkészültségi intézkedéseinek, valamint a polgárok önkéntes tevékenységeinek összehangolására. ${ }^{28} \mathrm{~A}$ finn védelmi politika arra épül, hogy a nemzetbiztonsági hatóságoknak már a különleges jogrend elrendelését megelőzően is legyen jogalapjuk fellépni a fenyegetésekkel szemben. ${ }^{29}$

A különleges jogrendszerre való felkészülés legfontosabb szerve a kormány, amely köré a teljes készültségi szervezetrendszer épül. A kormány feje a miniszterelnök, aki elnököl a plenáris ülésen, illetve az állandó bizottságokban. A kormány alkotja meg a társadalmi

\footnotetext{
24 Honvédelmi tv. 5. szakasz.

25 Honvédelmi tv. 6. szakasz.

26 Khakee, 2009, 26. o.

27 Honvédelmi tv. 27. szakasz.

28 Finnish Security and Defence Policy 2009. Government Report (84-85.) Elérhetô: www.files.ethz.ch/isn/156933/ Finland_English-2009.pdf (Letöltve: 2020. december 15.).

29 Például a krími helyzethez hasonló, felségjelzés nélküli katonák beszivárgásának elhárítása érdekében a határvédelmi törvény rendelkezéseit módosították (Salonius-Pasternak, 2019).
} 
biztonsági stratégiát, ${ }^{30}$ amely a felkészültség alapdokumentuma, és meghatározza a legfontosabb veszélyeket és kihívásokat. ${ }^{31}$ Kivételes körülmények fennállása esetén a kormány rendelete vezeti be a szükségállapotot. Finnország nem rendelkezik elkülönült nemzetbiztonsági csúcsszervvel, habár 1924-tôl az 1990-es évekig - hosszabb megszakításokkal - múködött a Védelmi Tanács, amely a honvédelmi stratégiáért felelős fó szerv volt. ${ }^{32} 2009$-ben felmerült annak lehetôsége, hogy életre hívjanak egy biztonsági tanácsot a komplex nemzetbiztonsági kihívások kezelése érdekében, ám ez végül sosem valósult meg. ${ }^{33} \mathrm{~A}$ kormány legfontosabb nemzetbiztonsági szerve a Külügyi és Biztonságpolitikai Miniszteri Bizottság, amely előkészíti a kül- és biztonságpolitika fontos szempontjait, valamint az egyéb ügyeket, amelyek érintik Finnország más államokkal fenntartott kapcsolatait, a kapcsolódó kulcsfontosságú belső biztonsági kérdéseket és az átfogó védelemmel kapcsolatos fontos kérdéseket. A bizottság elnöke a miniszterelnök, tagjai a külügyminiszter és a honvédelmi miniszter, valamint legfeljebb még négy, kormány által delegált miniszter, üléseit a köztársasági elnökkel közösen tartja. Tagjain kívül az ülésen még jelen van a belügyminiszter, ha az ő tárcáját érintő kérdést tárgyalnak, valamint bármely más miniszter. ${ }^{34}$

A miniszterelnök mellett múködő Miniszterelnöki Hivatal múködteti a Kormányzati Eseményközpontot, amelynek jogállását törvény tartalmazza. ${ }^{35}$ Ez valós időben követi a vészhelyzeti események kialakulását a beérkező adatok alapján, és egyúttal NATO és ENSZ polgári védelmi, valamint EU válságkezelési nemzeti kapcsolattartó pontként is funkcionál. A szerv a nyilvánosan elérhető, illetve a hatóságoktól kapott információk alapján figyeli a Finnországot érintő természeti katasztrófák, valamint fenyegetések alakulását. A szerv információkkal látja el a kormány Külügyi és Biztonságpolitikai Miniszteri Bizottságát.

Fontos szerep jut a minisztériumoknak, amelyek saját területükön felelnek a készültségért. A Belügyminisztérium az egyik legfontosabb ezek közül. A mentési múveletek mellett számos más, a krízisekre és balesetekre reagálás szempontjából releváns mưveletért is felelős, mint például a közrend és a közbiztonság, a rendőrség igazgatása, a magánbiztonsági szektor, a vészhelyzeti reagálási központok múveletei, a határbiztonság, a tengeri mentőszolgálatok, a nemzeti készültség, a polgári válságkezelés és a regionális közigazgatás felkészültsége a kivételes körülményekre és a zavarokra. ${ }^{36} \mathrm{Az}$ országot érintő veszélyek felmérése érdekében háromévente nemzeti kockázatelemzés készül, amely meghatározza az embe-

30 A nemzetközi gyakorlatban a nemzeti biztonsági stratégia fogalmának felel meg.

31 Elérhető: https://turvallisuuskomitea.fi/en/security-strategy-for-society/ (Letöltve: 2020. december 15.).

32 Penttila, 1991, 89-90. o.

33 A tervek szerint a tanács tagjai az ország legfőbb politikai vezetői, valamint a legfontosabb polgári és katonai tisztviselői lettek volna. A tanács a miniszterelnök felügyelete alatt múködött volna, és a biztonsági erőfeszítések összehangolása lett volna a feladata. Elérhető: https://yle.fi/uutiset/osasto/news/finland_considers_ establishment_of_national_security_council/5723069 (Letöltve: 2020. december 15.).

34 Elérhető: https://valtioneuvosto.fi/en/government/ministerial-committees (Letöltve: 2020. december 15.). 35 A Kormányzati Eseményközpontról szóló 300/2017. törvény (Laki valtioneuvoston tilannekeskuksesta).

36 Elérhető: www.ifrc.org/Global/Publications/IDRL/Publications/HNSG_EN_FINLAND\%202014.pdf (Letöltve: 2020 . december 15.). 
reket, a környezetet, a vagyont és a kritikus rendszereket és szolgáltatásokat fenyegetô különféle kockázatokat, amelyekre a hatóságoknak fel kell készülniük minden tevékenységük során..$^{37} \mathrm{~A}$ jelentést a Belügyminisztérium készíti el..$^{88}$

A Védelmi Minisztérium alatt múködik a Biztonsági Bizottság, amelyet 2013-at megelőzően Biztonsági és Védelmi Bizottságnak neveztek, jogállásáról pedig kormányrendelet rendelkezik. ${ }^{39} \mathrm{Ez}$ a szerv segíti mind a minisztériumot, mind a kormány Külügyi és Biztonságpolitikai Miniszteri Bizottságát az átfogó védelmi megközelítéssel kapcsolatos kérdésekben. Összesen húsz tagból és négy szakértőből áll, akik a kormányzatból, a közigazgatásból és az üzleti életből érkeztek. A bizottság havonta egyszer ülésezik, állásfoglalásokat és ajánlásokat készít az átfogó, védelemmel kapcsolatos kérdésekben, leggyakrabban a felelős minisztérium vagy más megrendelésére. A finn kiberbiztonsági stratégia és annak végrehajtási programja jó példa a bizottság irányítása alatt elvégzett munkára. ${ }^{40}$

\subsection{A válságkezelésre vonatkozó szabályok}

A finn válságkezelés nem rendelkezik egységes szabályozással, azt ágazati törvények szétszórtan tartalmazzák. A válsághelyzet, mint olyan, külön nevesítésre nem kerül, de bizonyos törvényi helyzetek megfeleltethetők a magyar válsághelyzeti szabályozásnak. A válságkezeléssel kapcsolatos legfontosabb rendelkezések az egészségügyi ellátásról ${ }^{41}$ és a fertőző betegségekről szóló törvényben, ${ }^{42}$ a mentési törvényben, ${ }^{43}$ a rendőrségi törvényben, ${ }^{44}$ valamint a bevándorlási törvényben találhatók. ${ }^{45}$

A katasztrófavédelmi szabályokat több finn törvény is részletezi. A legfontosabb ezek közül a Mentési tv., amely a polgári védekezés és felkészülés lehetőségeit részletezi. A törvény fố célja a tûz- és más balesetek megelőzése, felkészülés a balesetekre és a múveletekre, ha balesetveszély áll fenn, vagy ha baleset történik, illetve a balesetek következményeinek korlátozása. Ezeket úgy kell megtervezni és végrehajtani, hogy a kivételes körülmények fennállása esetén bevezetett szükségállapot során is elláthatók legyenek. ${ }^{46} \mathrm{~A}$ törvény meghatározza a „mentési múveletek” fogalmát, amelyek a mentőszolgálat olyan sürgős feladatai, amelyek célja az emberéletek, a vagyon és a környezet megmentése és védelme balesetveszély

37 Elérhető: https://intermin.fi/en/rescue-services/preparedness/national-risk-assessment (Letöltve: 2020. december 15.).

38 Elérhető: https://intermin.fi/julkaisut/julkaisu?pubid=URN:ISBN:978-952-324-249-4 (Letöltve: 2020. december 15.).

39 A Biztonsági Bizottságról szóló 77/2013. kormányrendelet (Valtioneuvoston asetus Turvallisuuskomiteasta).

40 Elérhető: https://turvallisuuskomitea.fi/en/security-committee/ (Letöltve: 2020. december 15.).

41 Terveydenhuoltolaki 1326/2010 (a továbbiakban: Eütv.).

42 Tartuntatautilaki 1227/2016 (a továbbiakban: Fertőzés tv.).

43 Pelastuslaki 29.4.2011/379 (a továbbiakban: Mentési tv.).

44 Poliisilaki 22.7.2011/872 (a továbbiakban: Rendőrségi tv.).

45 Ulkomaalaislaki 30.4.2004/301 (a továbbiakban: Bevándorlás tv.).

46 Mentési törvény 2. szakasz. 
esetén vagy baleset bekövetkeztekor, valamint a baleset okozta károk korlátozása és a baleset következményeinek enyhítése. ${ }^{47} \mathrm{~A}$ mentési mûveletekben fontos szerep jut a mentési múvelet irányítójának, aki vagy a mentési régióból érkezik, vagy a Belügyminisztérium delegálja. ${ }^{48}$ Ő többek között elrendelheti bizonyos területek kiürítését, szükséges esetben kárt okozhat az ingó és ingatlan vagyonban, elrendelheti a szükséges eszközök, kommunikációs vonalak, épületek elérhetôvé tételét, valamint minden egyéb szükséges lépést megtehet. A mentési munkában való részvételre minden munkaképes felnőtt kötelezhető a parancsnok által. ${ }^{49}$

A Rendőrségi tv. részletekbe menően szabályozza a rendőrségi eljárásokat, illetve rögzíti a titkos információgyűjtés korlátait. A rendőr polgári szabadságjogokat - így például a mozgásszabadságot korlátozó, a más tulajdonába való belépés jogát, egy adott terület lezárását vagy tömeg oszlatását lehetôvé tevő - korlátozó intézkedési jogkörét is ez a törvény határozza meg. ${ }^{50}$ Ezeket az intézkedési jogköröket a rendőr válsághelyzetben is gyakorolhatja - erre utalnak a törvénynek a „közrend, közbiztonság védelme érdekében” alkalmazott fordulatai. ${ }^{51}$ A belső zavargások kezelése már előkészületi állapotban is lehetséges a törvény alapján különböző rendőri intézkedésekkel, így például területlezárásokkal vagy tömegoszlatással. ${ }^{52}$ Egyes, belső zavargásokra utaló cselekményekkel kapcsolatban lehetőség nyílik a titkos információgyuujjtési módszerek alkalmazására is. ${ }^{53} \mathrm{~A}$ már megvalósult belső zavargások kezelésekor a rendőrség mellett a honvédség bevetése is lehetővé válik a Honvédelmi tv. révén. ${ }^{54}$

Az egészségügyi válságkezeléssel kapcsolatos szabályozás az Eütv.-ben és a Fertôzés tv.-ben található. Előbbi az ezzel kapcsolatos tervek elkészítését szabályozza, míg az utóbbi a fertőző betegségek és az általuk okozott járvány elleni védekezés részletszabályait tartalmazza. A Fertőzés tv. a hatásköröket (bejelentési és nyilvántartási kötelezettségek, információk megosztása és továbbítása, ellenőrzési feladatok és vizsgálatok lebonyolítása) központi, regionális és helyi szinten osztja meg, elsődleges célként pedig a megelőzést jelöli ki. A törvény rendelkezéseket tartalmaz például a karantén elrendeléséről és szabályairól, valamint az oktatási, egészségügyi, napközi, társasházi épületek bezárásáról, illetve a közterületeken történő gyúlések és nyilvános rendezvények korlátozásáról. A Fertőzés tv. alkalmazásában fertőző betegségnek számít az emberi testben szaporodó mikrobák, komponenseik vagy paraziták által okozott bármilyen betegség vagy fertőzés. ${ }^{55}$ Még ha a hatáskörök sok esetben decentralizáltak is, a gyakorlat azt mutatta, hogy ezek központi

47 Mentési törvény 2. szakasz (2) bekezdés.

48 Mentési törvény 34. szakasz.

49 Mentési törvény 36-37. szakasz.

50 Rendőrségi tv. II. fejezet 2., 6., 8., 9., 10-19. szakasz.

51 A más tulajdonába való belépés jogát biztosító törvényhely például már életet, egészséget, személyes szabadságot, vagyonbiztonságot vagy a környezetet érintő cselekedet vagy esemény bekövetkeztének veszélye esetén is lehetővé teszi a rendőr fellépését (Rendőrségi tv. II. fejezet 6. szakasz).

52 Rendőrségi tv. II. fejezet 2-19. szakasz.

53 Rendőrségi tv. V. fejezet 2-3. szakasz.

54 A védelmi erőkről szóló törvény (Laki puolustusvoimista 11.5.2007/551) 2. szakasz (1) bekezdés b) pontja és (2) bekezdés a) pontja.

55 Fertőzés tv. 3. szakasz. 
kormányzati összehangolására van szükség a koronavírushoz hasonló nagyobb járvány esetén. ${ }^{56}$ A törvényhez tartozik egy rendelet is, amely a fertőző betegségek listáját tartalmazza. ${ }^{57}$

A tömeges bevándorlással kapcsolatos szabályozás - amit a magyar jog külön jogintézményként bontott $\mathrm{ki}^{\mathrm{i}}{ }^{8}$ - a finn jogban a bevándorlási törvényben nyert elhelyezést, egy egészen rövid technikai utalás formájában. Eszerint, ha olyan nagyszámú bevándorló érkezik az országba, hogy nem lehetséges meghatározni a beutazás feltételeit és a bevándorlókat rendes eljárás szerint nyilvántartásba venni, a kormány legfeljebb három hónapig terjedő időre dönthet speciális menekültügyi központokba kerülésükről, amelyet tilos elhagyniuk a nyilvántartásba vétel idejéig. ${ }^{59}$

\section{Az alapjogok korlátozására vonatkozó szabályok különleges jogrend idején}

Az alkotmány egyetlen különleges jogrenddel kapcsolatos rendelkezése az alapjogok korlátozásával kapcsolatos. ${ }^{60} \mathrm{Az}$ alkotmány nem nevesíti egyértelmúen a kormányt mint a különleges jogrend elrendelőjét és felhatalmazottját. A Vészhelyzeti tv. pótolja ezt a hiányosságot, ennek a felhatalmazásnak pedig két korlátja van: először is a parlament jelentős szerepe az egyes alapjog-korlátozó rendelkezések felülvizsgálatában, másrészt a nemzetközi kötelezettségeknek való megfelelés követelménye. ${ }^{61} \mathrm{~A}$ koronavírus-járvány idején történő gyakorlat azt mutatja, Finnország nagy hangsúlyt helyez arra, hogy a végrehajtó hatalom határozatainak alkotmányosságát és jogi megfelelőségét állandó bizottságok, illetve külső alkotmányjogi szakértők segítségével biztosítsa különleges jogrend idején is. ${ }^{62}$

A Vészhelyzeti tv. számos rendelkezést tartalmaz, amelyek felhatalmazása alapján a kormány, minisztérium vagy más szerv alapjog-korlátozó rendelkezést hozhat szükségállapot idején. Ezek a rendelkezések nem általánosak, hanem az alkalmazható eszközök felsorolását adják. Fontos megjegyezni, hogy mindezen eszközök mellett az alkotmány 23. szakasza alapján bármilyen más alapjog-korlátozó jogszabály megalkotható a különleges jogrend idején, az egyetlen különbség, hogy rendeleti forma helyett törvényként kerül elfogadásra. A törvényben szereplő eszközök részletes feldolgozása szétfeszítené a tanulmány kereteit, így csak a legfontosabb csoportok bemutatására kerül sor.

A Vészhelyzeti tv. először a pénzügyi piacok biztonságát érintő intézkedésekkel foglalkozik, így például értékpapírok, pénz kivitele vagy behozatala csak a nemzeti bank engedé-

56 Scheinin, 2020.

57 A fertőző betegségekről szóló kormányrendelet (Valtioneuvoston asetus tartuntataudeista 146/2017).

58 A menedékjogról szóló 2007. évi LXXX. törvény X/A. fejezet.

59 Bevándorlási tv. 133. szakasz.

60 Alkotmány 23. szakasz.

61 Cornell-Salminen, 2018, 242. o.

62 Grogan, 2020. 
lyével lehetséges, az állampolgárok kötelezhetők a külföldi valuta leadására, ahogy az állampolgárok külföldi tranzakciói is korlátozhatók. ${ }^{63} \mathrm{Az}$ exporttilalom alól azonban mentességet lehet adni, például ha az szükséges a lakosság jólétéhez és az ország gazdaságának müködéséhez, vagy külföldi finn tulajdonnal függ össze. ${ }^{64}$ További rendelkezések a hitelezéssel, valamint a biztosításokkal, illetve az értékpapírok kibocsátásával, kereskedelmével kapcsolatosan tartalmaznak korlátozásokat, bizonyos sebezhető fizetési módozatok kizárását teszik lehetővé, valamint a csőd- és felszámolási eljárások esetén teszik lehetővé bizonyos kivételek alkalmazását. ${ }^{65}$

Az eszközök következő csoportja az áruk előállításának és elosztásának, valamint az energiaellátásnak a biztosítása kapcsán tartalmaz rendelkezéseket. Itt különféle korlátozásokat állapít meg a törvény, így például az üzemanyagok hatósági vételárassá tehetők, bizonyos, mezőgazdaságban használatos javak birtoklása és kereskedelme korlátozható, a kiskereskedelmi áruforgalom, illetve az iparban szükséges fémek, ötvözetek, elektromos eszközök stb. használata korlátozható. ${ }^{66}$ Korlátozható továbbá a külföldre irányuló áruforgalom, az elektromos hálózat használata, sőt, akár fel is függeszthetô, a távfútés korlátozható, valamint a fütőolaj kereskedelmének korlátozása is elrendelhetô. ${ }^{67}$

A Vészhelyzeti tv. az építési projektekkel, valamint az építőanyagokkal kapcsolatosan is tartalmaz rendelkezéseket. Így például a szükségállapot ideje alatt az építkezések elkezdése, illetve folytatása külön engedélyhez köthető, ahogy az építőanyagok beszerzése is engedélykötelessé tehető. ${ }^{68} \mathrm{~A}$ lakhatással kapcsolatosan is megfogalmazódnak szabályok, így például előírható, hogy a lakáskiadó tulajdonos bejelentse a bérlőjét a megfelelő hatóságnál, ahogy ideiglenesen a lakbér emelése is tilalmazható. ${ }^{69} \mathrm{Az}$ eszközök következő csoportja a társadalombiztosítással kapcsolatos. Így például a kötelező biztosítás és az ellátás három hónapig terjedő időre felfüggeszthetô vagy elhalasztható, vagy a kifizetés mértéke legfeljebb felére csökkenthető, ami vonatkozik egyes speciális ellátásokra is (például anyasági támogatás, nemzetközi örökbefogadás támogatása, tartásdíj). ${ }^{70} \mathrm{~A}$ törvény tartalmaz eszközöket az elektronikus információs és kommunikációs rendszerek múködésének és a postai szolgáltatások elérhetőségének biztosítására is, így például a rádiófrekvenciákkal kapcsolatos döntéseket, illetve a különböző biztonsági intézkedések kötelező elôirásának a lehetőségét, valamint a telekommunikációs és infokommunikációs szolgáltatás üzemeltetését ideiglenesen a megfelelő minisztérium alá rendelheti. ${ }^{71}$

63 Vészhelyzeti tv. 15. szakasz.

64 Vészhelyzeti tv. 16. szakasz.

65 Vészhelyzeti tv. 17-23. szakasz.

66 Vészhelyzeti tv. 30-34. szakasz.

67 Vészhelyzeti tv. 35-41. szakasz.

68 Vészhelyzeti tv. 47-48. szakasz.

69 Vészhelyzeti tv. 51-55. szakasz.

70 Vészhelyzeti tv. 58-59. szakasz.

71 Vészhelyzeti tv. 61-64. szakasz. 
Az eszközök következő nagy csoportja a közlekedés és az üzemanyag-ellátás kérdéseivel foglalkozik. Ez alapján korlátozások vezethetők be az üzemanyag-kereskedelem, ${ }^{72}$ valamint a közúti közlekedés igénybevétele terén, ${ }^{73}$ a tulajdonosok kötelezhetôk a gépjármúvek átadására. ${ }^{74}$ Korlátozás alá vonható a vízi közlekedés és a légi közlekedés, és az ezen eszközök múködéséhez szükséges üzemanyag kereskedelme korlátozható. Korlátozható ezenkívül a vasúti közlekedés is. ${ }^{75} \mathrm{~A}$ törvény következő eszközcsoportja a szociális és egészségügyi intézmények feladataival kapcsolatos. Így például a kórházakban gondozásra szoruló személyeket a kezelőegységben helyezhet el, korábbi megegyezéstől vagy előirástól függetlenül. ${ }^{76}$ Az intézkedések következő csoportja a munkavállalás kérdéseivel foglalkozik, így külön kormányrendelet határozhatja meg bizonyos, az adott vészhelyzettel kapcsolatban kiemelt jelentőségú szektorokban (például egészségügy, állami szféra stb.) az új munkatársak felvételével, a béremelés mértékével kapcsolatos szabályokat, eltérést engedhet a munkaszerződéstől például a munkaórák és pihenőidő tekintetében, valamint korlátozhatja az elbocsátásokat. ${ }^{77} \mathrm{~A}$ törvény alapján lehetőség van munkakötelezettség megállapítására a megfelelő, létfontosságú szektorokban (külön nevesítve az egészségügyi képzettséggel rendelkezőket), amely a 18 és 67 év közöttiekre vonatkozik. Számukra a hatóságok állíthatnak ki munkautasítást, meghatározva a munkakötelezettség helyét és idejét. ${ }^{78} \mathrm{~A}$ munkaügyi hatóság állítja ki a munkarendet a munkavállaló számára, ugyanakkor ennek korlátait maga a törvény tartalmazza. ${ }^{79} \mathrm{~A}$ törvény lehetőséget biztosít a közigazgatási szervezetrendszert és múködést érintő kérdések ideiglenes átszervezésére is. ${ }^{80}$ Elkülönítve tartalmazza a törvény a katonai készültséggel kapcsolatos szabályozást: ezek az intézkedések részben már szerepelnek a törvényben, annyi különbséggel, hogy nem a civil hatóságok, hanem a védelmi erők rendelkezhetnek annak alkalmazásáról. Így például előírhatják javak bizonyos kötelező leadását, bizonyos szolgáltatások nyújtását, szárazföldi, vízi, légi jármúvek átadását, bizonyos magánterületek átadását. ${ }^{81}$ Végezetül a törvény a mentésben részt vevő szervek számára teszi lehetôvé hasonló különleges jogkörök gyakorlását. ${ }^{82}$

A Honvédelmi tv. először az általános rendelkezéseket fogalmazza meg, így például az olyan személy, akiről feltételezhető, hogy hazaáruló vagy más módon veszélyezteti a védelmi erőfeszítéseket, kötelezhető a rendőrség által meghatározott helyen maradni, a lakhe-

72 Vészhelyzeti tv. 67-73. szakasz.

73 Vészhelyzeti tv. 74-76. szakasz.

74 Vészhelyzeti tv. 78. szakasz.

75 Vészhelyzeti tv. 79-83. szakasz.

76 Vészhelyzeti tv. 86. szakasz.

77 Vészhelyzeti tv. 91-94. szakasz.

78 Vészhelyzeti tv. 95. szakasz.

79 Vészhelyzeti tv. 97-99. szakasz.

80 Vészhelyzeti tv. 104-109. szakasz.

81 Vészhelyzeti tv. 110-113. szakasz.

82 Vészhelyzeti tv. 116-122. szakasz. 
lyének elhagyására kötelezhető vagy pedig az ellenőrzés alá vonható. ${ }^{83}$ Ezzel szemben fellebbezéssel lehet élni a helyi bíróság felé, ugyanakkor az érintett rendőrségi őrizetbe vehetô, amíg bíróság dönt a kérdésről. ${ }^{84}$ Amennyiben valamilyen egyesület veszélyeztette a védelmi erőfeszítéseket, úgy a kormány részben vagy egészben felfüggesztheti annak múködését. ${ }^{85} \mathrm{~A}$ gyứlések előzetes, írásban történő bejelentésének kötelezettsége elôirható, amit legkésőbb három nappal az esemény elôtt írásban kell megtenni. ${ }^{86}$ Amennyiben a gyúlés veszélyezteti a védelmi erőfeszítéseket, úgy a rendőrség dönthet úgy, hogy nem engedélyezi. A regionális közigazgatási szervek korlátozhatják vagy megtilthatják az utcai tartózkodást, ha a védelem érdekei ezt kívánják. ${ }^{87}$

A Honvédelmi tv. ezt követően a katonai és gazdasági védelem speciális eszközeit taglalja. A kormány például elooírhatja a vállalatoknak bizonyos javak eloállítását, és megtilthatja más javak elóállítását, ${ }^{88}$ míg a Belügyminisztérium dönthet bizonyos javak elkobzásáról vagy állami felügyelet alá helyezésérooll. ${ }^{89} \mathrm{~A}$ katonai hatóságok főleg operatív kérdésekben dönthetnek, például a lakosság kitelepítéséről a harcok által érintett területen, ám ezen döntések időben korlátozottak, két hetet meghaladó időtartam esetén a kormánynak kell döntenie róluk.90

\section{A koronavírus-járványra adott állami reakció}

Finnországban már a járvány kitörését követően nem sokkal, 2019. novemberben ülésezett a kormány a szükségállapot bevezetésének feltételeivel kapcsolatosan. ${ }^{91} \mathrm{Az}$ első koronavírus-fertőzöttet 2020. január 29-én találták meg. A vírus felkerült a fertőző betegségek jogszabályi listájára egy február 13-i döntéssel. A fertőzések száma az országban március elején ugrott meg, miután az előző hónapban az Alpokban síelő finn turisták hazatértek. ${ }^{92}$ Erre válaszul március 16-án a köztársasági elnök és a kormány a szükségállapot bevezetése mellett döntött, az ország történetében először a vonatkozó törvények elfogadása óta.93 A kivételes körülmények alapján az egészségügyi és gazdasági vészhelyzet is megállapításra került, mint a szükségállapot jogalapja. ${ }^{94}$ Számos intézkedésre került sor a Vészhelyzeti tv.

83 Honvédelmi tv. 8. szakasz.

84 Honvédelmi tv. 9. szakasz.

85 Honvédelmi tv. 10. szakasz.

86 Honvédelmi tv. 11. szakasz.

87 Honvédelmi tv. 12. szakasz.

88 Honvédelmi tv. 17. szakasz.

89 Honvédelmi tv. 20. szakasz.

90 Honvédelmi tv. 23-27. szakasz.

91 Elérhető: www.helsinkitimes.fi/finland/finland-news/domestic/18360-finland-close-to-but-not-quite-yetin-state-of-emergency-write-hs-and-yle.html (Letöltve: 2020. december 15.).

92 Tiirinki et al., 2020.

93 Salminen, 2020, 1116. o.

94 Scheinin, 2020. 
és más törvények releváns rendelkezései alapján. ${ }^{95}$ Habár a fertőzések elsősorban a fôváros, Helsinki régióját érintették, a korlátozó intézkedések alkalmazását az egész országra elrendelték. Az intézkedések mögött teljes politikai egyetértés állt. ${ }^{96}$

A kormány összesen mintegy húsz rendeletet adott ki, illetve hosszabbította meg azok hatályát a Vészhelyzeti tv. alapján az egészségügyi és szociális ellátóegységek múködésével kapcsolatban; az egészségügyi szolgáltatásokban használt gyógyszerek, áruk és szolgáltatások értékesítésének korlátozásáról; egészségügyi és szociális jóléti szolgáltatásokról és egészségvédelemről; a munkaviszonyok és az elbocsátások feltételeitől való eltéréseket állapítottak meg, illetve munkakötelezettséget, valamint az iskolák és más oktatási intézmények bezárásáról rendelkeztek. A kormány 2020. március 28. és április 15. között korlátozta az emberek mozgását Uusimaa régió és az ország más területei között. Az éttermek, kávézók és bárok zárva voltak május 31-ig, kivéve az elviteli és kiszállítási szolgáltatásokat. ${ }^{97}$ Míg a kormányrendeletek többségét a Vészhelyzeti tv. alapján fogadták el, ez utóbbi jogszabályt az alkotmány 23. szakaszában foglalt rendkívüli helyzetekben alkalmazható alapjog-korlátozási lehetőség alapján alkották meg, törvényi formában.$^{98}$ Egyéb intézkedésekre is sor került, amelyeket nem a szükségállapot alapján, hanem a vonatkozó ágazati törvények alapján hoztak meg. Például a határellenőrzés szigorítására a határőrségről szóló törvény99 alapján került sor. ${ }^{100}$

Fontos ugyanakkor megjegyezni, hogy a tényleges jogi korlátozások mellett számos soft law jellegú, javaslati formájú rendelkezésre is sor került a Fertőzés tv. előírásai szerint. Így például a társadalmi távolságtartás vonatkozásában, amelyet csak javasoltak a hatóságok a munkáltatóknak és a közvéleménynek. ${ }^{101} \mathrm{~A}$ Szociális és Egészségügyi Minisztérium létrehozott egy munkacsoportot a szociális és egészségügyi területen hozott intézkedések tervezésére, végrehajtására és koordinálására. Ezzel együtt több hazai és nemzetközi ügynökséggel is egyeztetéseket indított a gyógyszerészeti szolgáltatások és ellátás folyamatosságának biztosítása érdekében. Ajánlásokat fogalmaztak meg a helyi és regionális hatóságoknak, illetve a munkáltatóknak a fertőzés terjedésének visszaszorítása érdekében. ${ }^{102}$ A korlátozások mellett a finn kormány jelentős összegeket fordított a bajba jutott vállalkozások megsegítésére, amelyek összege nyárra elérte a 15 milliárd eurót is. ${ }^{103}$

$95 \mathrm{Az}$ intézkedések teljes listáját lásd: Tiirinki et al., 2020 (2. táblázat).

96 Moisio, 2020.

97 Elérhető: www.europarl.europa.eu/RegData/etudes/BRIE/2020/651972/EPRS_BRI(2020)651972_EN.pdf(Letöltve: 2020 . december 15.).

98 A szállás- és vendéglátóhelyekról szóló törvény ideiglenes módosítása (Laki majoitus- ja ravitsemistoiminnasta annetun lain väliaikaisesta muuttamisesta 153/2020); lásd még: Scheinin, 2020.

99 2005/578. Rajavartiolaki (a továbbiakban: Határőrség tv.).

100 Salminen, 2020, 1117. o.

101 Scheinin, 2020.

102 Elérhető: https://valtioneuvosto.fi/en/information-on-coronavirus/ministry-of-social-affairs-and-health (Letöltve: 2020. december 15.).

103 Moision, 2020. 
A különleges jogrend bevezetésével és alkalmazásával kapcsolatosan több probléma is felmerült. Ezek némelyike általános az ilyen helyzetekben, így például az alapjogok sérülése és a kormányzati hatalom növekedése, ezzel összefüggésben pedig a felelősségi kérdések elmosódása. ${ }^{104}$ Specifikus problémák is említhetők azonban, így például az, hogy bár a gazdasági vészhelyzet is jogalapként került feltüntetésre a szükségállapot bevezetésénél, a gazdasági intézkedésekre végül nem a törvény keretei között került sor. Problémát jelentett továbbá a Vészhelyzeti tv. komplikált felépítése, amelynek alkalmazása sokszor nem állt összhangban az alkotmány 23. szakaszával. A szükségállapoti kormányrendeletek megfogalmazása a megfelelő jogi és alkotmányos ismeretek hiányáról árulkodott, sokszor túl egyszerủ volt a megszövegezés, az nem hivatkozott az elfogadás jogalapjára és a nemzetközi kötelezettségeknek való megfelelőségre. A jogi szakértelem hiánya a törvényhozásnál is hiányzott, ahol sokszor nem bontották ki egy-egy kérdés nemzetközi jogi dimenzióját, illetve bizonyos esetekben az alkotmányosság háttérbe szorult a politikai konszenzus mögött. Sok esetben a nemzetközi jogi kötelezettségek teljesítése a háttérbe szorult, ami azért is különösen fontos, mert az alkotmány nem határoz meg korlátozhatatlan alapjogokat, ebben teljes egészében a nemzetközi jogi instrumentumokra bízva a jogalkotót. Uusimaa régió - ahol a népesség harmada él - elszigetelése az ország többi részétől csak mint a mozgásszabadság korlátozása került a jogalkotó elé, ugyanakkor a régióban magában nem vezettek be az ott élő veszélyeztettek védelmére szolgáló korlátozó intézkedéseket, ami a legrosszabb esetben közvetetten az ott élók élethez való jogát is súlyosan érinthette volna. ${ }^{105}$

Maga a törvényhozás Alkotmányjogi Bizottsága is számos alkalommal fogalmazott meg kritikát azzal kapcsolatosan, ahogy a kormány a különleges jogrendi helyzetet és a kapcsolódó jogalkotást kezeli. ${ }^{106}$ Például szóvá tette azt, hogy habár az elrendelés alapjának tette meg, a kormány egyetlen rendelkezése sem alapul a gazdasági vészhelyzeten ${ }^{107} \mathrm{~A}$ bizottság meglehetősen kritikusnak bizonyult, és bár minden rendelkezést jóváhagyott, ezek rendszeresen tartalmaztak valamilyen kritikát. Két esetben maga a kormány döntött a rendelet visszavonásáról a súlyos kritikák hatására, ezek esetén könnyedén elképzelhető, hogy azokat a törvényhozás nem hagyta volna hatályban. ${ }^{108}$ Uusimaa régió elszigetelése az ország többi részétől az egyik legnehezebb döntésnek bizonyult a járvány kezelése során. A szigorú parlamenti felülvizsgálatnak is köszönhetően a kormány megnövekedett hatalma nem vezetett autoriter törekvésekhez. ${ }^{109}$

Számos pozitívumot is el lehet azonban mondani a finn járványkezelésről. Bár a törvényhozás kiemelt szerepe a rendkívüli jogalkotásban lassítja és nehezíti az eredményes fel-

104 Salminen, 2020, 1117. o.

105 Scheinin, 2020.

106 Salminen, 2020, 1117. 0.; Neuvonen, 2020.

107 Salminen, 2020, 1124. 0 .

108 Salminen, 2020, 1124-1225. o.

109 Makarychev-Romashko, 2021. 
lépést, jogi biztosítékot is jelent a hatalmi túlkapások ellen. Ez azért is különösen fontos, mivel az országban nem múködik elkülönült alkotmánybíróság. ${ }^{10}$ Egyértelmúen a jó gyakorlatok közé sorolható, hogy külső jogi és alkotmányjogi szakértőket is bevontak a döntések alkotmányosságának vizsgálatába. ${ }^{111} \mathrm{Az}$, hogy számos esetben jogi kötőerôvel nem bíró ajánlásokat tettek a polgároknak a jogi kikényszerítés helyett, segített fenntartani a normalitás érzését. Az összes meghozott rendelet tartalmazott alkalmazási határidőre vonatkozó klauzulát a törvény szövegével összhangban. ${ }^{112}$ Számos olyan intézkedés került bevezetésre, amely a lezárások alatt a polgárok mentális egészségének és szabadságának megőrzésére szolgáltak, ami az egész társadalom összefogásával valósult meg. ${ }^{113}$

2020. május 6-án a kormány bejelentette, hogy Finnország „hibrid stratégiára” tér át, ami azt jelenti, hogy a korlátozásokat lassan megszüntetik, és a nagy tömegrendezvényekkel, éttermekkel kapcsolatos szigorú szabályozások és az idősek védelme kerül előtérbe. ${ }^{114}$ Május 14-én folytatódott az iskolai oktatás, és megindult a határokon a közlekedés. Június 1-jére engedélyezték az 50 fő alatti köztéri gyưléseket, és a nyilvános helyek újra kinyitottak. Június 15-én a kormány döntött a szükségállapot végéről, és azt június 16-i hatállyal megszüntette. ${ }^{115}$

\section{A különleges jogrend a gyakorlatban, viták és kihívások}

Mint a térség számos államában, a finn függetlenedés történelme is szorosan összekapcsolódik a különleges jogrenddel. ${ }^{116} \mathrm{~A}$ fiatal ország függetlensége számára a fenyegetés elsősorban kívülrôl érkezhetett, így az elsődleges cél a külső fegyveres veszély elhárítása volt. Ennek megfelelően különleges jogrendról csak háborús helyzetben lehetett beszélni. ${ }^{117} \mathrm{~A}$ nem fegyveres agresszióhoz kapcsolódó különleges jogrendi szabályozás kidolgozása egészen az 1990-es évekig váratott magára, ekkor fogadták el az első vészhelyzeti törvényt, amely a Honvédelmi tv.-ben található védelmi állapottól elkülönülten szabályozta a különleges jogrendet. Az 1999-ben elfogadott alkotmány megreformálta Finnország jogrendszerét, és hamarosan nyilvánvaló vált, hogy a korábbi vészhelyzeti törvény az új alkotmányba ütközik, ezért 2011-ben felváltották azt a jelenleg hatályos törvénnyel. Bár a cél az volt, hogy az alkotmányos rendbe illeszkedő új tör-

110 Neuvonen, 2020.

111 Grogan, 2020.

112 Scheinin, 2020.

113 Makarychev-Romashko, 2021.

114 Elérhető: https://valtioneuvosto.fi/-/10616/valtioneuvoston-periaatepaatos-suunnitelmasta-koronakriisinhallinnan-hybridistrategiaksi (Letöltve: 2020. december 15.).

115 Elérhető: www.europarl.europa.eu/RegData/etudes/BRIE/2020/651972/EPRS_BRI(2020)651972_EN.pdf(Letöltve: 2020. december 15.).

$116 \mathrm{Az}$ ország hosszú évszázadokon keresztül állt előbb svéd, majd orosz uralom alatt, és függetlenségét csak 1917-ben nyerte vissza, amelyet rögtön a fehérek és vörösök közötti polgárháború követett 1918-ban. Orosz szomszédjával ezt követően többször háborúra kényszerült (Moisio, 2020).

117 Cornell-Salminen, 2018, 238. o. 
vényt hozzanak, a kormányzat széles körú felhatalmazása, valamint a gazdasággal kapcsolatos esetkörök különleges jogrend alá vétele komoly alkotmányjogi aggályokat vetett fel. Mindezen okokból került sor a törvény kivételes jogalkotási eljárással történő elfogadására, amely azonban ma már igen ritkán alkalmazott megoldás, és sok kritikára adott okot. ${ }^{118}$

Felmerült annak lehetősége, hogy bizonyos jogok jelenlegi szúk korlátozásán túlmenően szélesebb körü beavatkozást tegyenek lehetôvé, de ez az elképzelés elhalt. İgy, bár a hatályos törvényben jelentőségét csökkentették valamelyest, igen érdekes módon továbbra is jelentős szerep jut a törvényhozásnak a különleges jogrend alkalmazása során. A különleges jogrendi szabályozás semmilyen útmutatást nem tartalmaz arra az esetre, ha a parlament valamilyen okból nem tudna összeülni. A jelenleg hatályos törvény sokkal inkább konform a 2012-es finn alkotmányreform utáni alkotmányos renddel, mint azt megelőzően, ám a kivételes jogalkotással történő elfogadás, valamint az a tény, hogy tisztán gazdasági esetkörök továbbra is a szükségállapot alá tartoznak, továbbra is komoly alkotmányjogi aggályokat vet fel. ${ }^{119}$

2000 óta számos változás történt a különleges jogrend szabályozásában. Először is, a kivételes körülmények fogalmát egyszerúsítették, hogy jobban illeszkedjen Finnország nemzetközi kötelezettségvállalásaihoz. Másodszor, az alkotmány 2012. évi felülvizsgálata után már nem szükséges, hogy minden esetben a törvényhozás alkossa meg az alapvető jogokat korlátozó jogszabályokat, hanem törvény - így a Vészhelyzeti tv. - felhatalmazása alapján a kormány is alkothat ilyen jogszabályt. ${ }^{120}$

A Vészhelyzeti tv.-t a megalkotása óta csak egyetlen alkalommal alkalmazták, a koronavírus-járvány idején, 2020 tavaszán. Ennek megfelelően a törvénnyel kapcsolatos bírósági joggyakorlat sem alakult ki, azzal nem foglalkoznak bírói ítéletek.

\section{5. Összegzés}

Az alábbi táblázat tartalmazza a finn különleges jogrendi esetkörökkel kapcsolatos legfontosabb szabályozásokat:

118 Cornell-Salminen, 2018, 240-241. o.

119 Cornell-Salminen, 2018, 245. o.

120 Cornell-Salminen, 2018, 246. o. 


\begin{tabular}{|c|c|c|}
\hline & Szükségállapot & Védelmi állapot \\
\hline $\begin{array}{l}\text { Szabályozás } \\
\text { szintje }\end{array}$ & \multicolumn{2}{|c|}{$\begin{array}{l}\text { Minimális alkotmányos, részletes törvényi } \\
\text { (Vészhelyzeti tv., Honvédelmi tv.) }\end{array}$} \\
\hline Elrendelési okok & $\begin{array}{l}\text { — fegyveres vagy hasonló támadás } \\
\text { Finnország ellen és annak közvetlen } \\
\text { következményei } \\
\text { — Finnország elleni fegyveres vagy } \\
\text { hasonló támadás jelentős veszélye } \\
\text { — a lakosság megélhetését vagy } \\
\text { az ország gazdaságának alapjait } \\
\text { különösen súlyosan érintő esemény } \\
\text { vagy veszély, amelyek jelentős } \\
\text { kockázatot jelentenek a társadalom } \\
\text { létfontosságú funkcióira } \\
\text { — súlyos baleset és annak közvetlen } \\
\text { következményei } \\
\text { — nagyon széles körben elterjedt ve- } \\
\text { szélyes fertőző betegség }\end{array}$ & $\begin{array}{l}\text { — külső fegyveres fenyegetés } \\
\text { — az alkotmányos rend megváltoz- } \\
\text { tatására irányuló belső erőszakos } \\
\text { zavargások }\end{array}$ \\
\hline Elrendelés & $\begin{array}{l}\text { — A kormány és a köztársasági elnök } \\
\text { közösen dönt róla, majd a kormány } \\
\text { kormányrendeletet alkot; } \\
\text { _ az intézkedéseket tartalmazó kor- } \\
\text { mányrendeletek vonatkozásában } \\
\text { a törvényhozás dönt; } \\
\text { — ezek három, illetve hat hónapig } \\
\text { alkothatók meg, hatályuk egy } \\
\text { alkalommal legfeljebb hat hónappal } \\
\text { meghosszabbítható, parlamenti } \\
\text { jóváhagyással. }\end{array}$ & $\begin{array}{l}\text { - A köztársasági elnök rendeletben } \\
\text { dönt a bevezetésről; } \\
\text { — az alapján hozott rendelkezés } \\
\text { legfeljebb három hónapra hozható, } \\
\text { a parlament megerősítése szük- } \\
\text { séges hozzá; } \\
\text { — hatálya egy évvel } \\
\text { meghosszabbítható. }\end{array}$ \\
\hline Felhatalmazott & \multicolumn{2}{|c|}{ A kormány, minisztériumok, a Védelmi Erők } \\
\hline $\begin{array}{l}\text { Előkészítő } \\
\text { szervek }\end{array}$ & \multicolumn{2}{|c|}{$\begin{array}{c}\text { A kormány Külügyi és Biztonságpolitikai Miniszteri Bizottsága, Biztonsági } \\
\text { Bizottság, Kormányzati Eseményközpont, minisztériumok }\end{array}$} \\
\hline Gyakorlati esetek & Covid-19-járvány kezelése & Nincs \\
\hline $\begin{array}{l}\text { Különleges } \\
\text { jogrendnek nem } \\
\text { minősülő rend- } \\
\text { kívüli helyzet }\end{array}$ & \multicolumn{2}{|c|}{ Nem kerül nevesítésre, több törvény is tartalmaz rendelkezéseket. } \\
\hline
\end{tabular}

\section{8. táblázat}

Finnország különleges jogrendi szabályozásának összefoglalása

Forrás: a szerző saját szerkesztése 
A finn különleges jogrend szabályozása sok szempontból sajátosnak mondható. Az alkotmány a különleges jogrend kérdésében nem tartalmaz rendelkezéseket, csak az alapjog-korlátozás szempontjából. ${ }^{121}$ Ez lehetőséget teremt arra, hogy háború, illetve egyéb krízishelyzet esetén az alapjogokat korlátozzák. Az érdemi szabályozást két törvény tartalmazza: a védelmi helyzet szabályozását a Honvédelmi tv., a szükségállapot szabályozását a Vészhelyzeti tv. Utóbbi érdekessége, hogy úgynevezett kivételes jogalkotási eljárásban került elfogadásra, ami azt jelenti, hogy tartalma kivételt jelent az alkotmány alól, tulajdonképpen szétfeszíti az alkotmány kereteit, és saját tartalommal tölti ki azokat. Ennek megfelelően az elfogadási eljárása az alkotmánymódosításokéhoz hasonló. Ezt a fajta jogalkotást a finn jogalkotó is sok kritikával illeti, és igyekszik mellőzni használatát. Hogy végül mégis így került sor a törvény elfogadására, annak köszönhető, hogy a különleges jogrendi szabályozás és az alkotmány reformja párhuzamosan futott, és rendes eljárásban a törvény nem illeszkedett volna megfelelően az új alkotmány előírásaihoz (például a kizárólag gazdasági jellegú esetkörök különleges jogrend alá vonása miatt), rákényszerítve ezzel a jogalkotót a kivételes jogalkotási eljárásra.

A szükségállapot elrendelésére kivételes körülmények fennállása esetén kerülhet sor, ezek listáját a törvény részletesen felsorolja. Ezek között szerepel a fegyveres támadás vagy annak közvetlen veszélye, olyan veszély, amely súlyosan fenyegeti a társadalom létfontosságú funkcióit, súlyos baleset, illetve súlyos fertőző betegség. Védelmi állapotot külső fegyveres támadás, illetve az alkotmányos rend megváltoztatására irányuló belső erőszakos zavargások esetén lehet elrendelni. A szükségállapot bevezetéséról a kormány és a köztársasági elnök közösen dönt, míg a védelmi állapotról a köztársasági elnök dönt. A finn szabályozás újabb sajátossága itt is megtalálható: a különleges jogrend bevezetéséról szóló döntés semmilyen parlamenti kontroll alatt nem áll, alkalmazásának határideje sincs meghatározva. Ahol a törvényhozás szerepe jelentős, az az egyes jogkorlátozó, úgynevezett végrehajtási rendeletek felülvizsgálata, amelyet az adott törvények részletes katalógusa alapján hozhatnak meg. Ezek már rendelkeznek alkalmazási határidővel, szükségállapot esetén ez általánosan hat hónap, sürgősség esetén három hónap, egyszeri hat hónapos hosszabbítási lehetőséggel. A védelmi állapotnál a határidő három hónap, amely egyszeri alkalommal hat hónappal meghosszabbítható. A végrehajtási rendeletek azonnal hatályba lépnek, ám alkalmazásuk nem történhet meg addig, amíg a törvényhozás felül nem vizsgálja őket (kivétel a sürgősségi rendeletek). Bár nevesítésre nem kerül, a törvény alapján egyértelmú, hogy a szükségállapot esetén a kormány, míg a védelmi állapot esetén a köztársasági elnök szerepe jelentős. A két vonatkozó jogszabály együttes alkalmazása - törvény eltérő rendelkezése nélkül - nem kizárt, a két típus közül a védelmi állapot számít súlyosabbnak.

A finn szabályozás alapelve, hogy a jogalkotó csak a legvégső esetben nyúljon a különleges jogrend eszköztárához. Ennek megfelelően az egyes ágazati törvények is széles körü 
jogosítványokat tartalmaznak a kivételes körülmények szintjét el nem érô események kezelésére. Például a Határőrség tv. lehetôvé teszi a határôrizet szigorítását, a Fertőzés tv. járványügyi intézkedések meghozatalát, a Rendőrségi tv. jogosítványokat biztosít a zavargások kezelésére, míg a Mentési tv. „mentési műveletek” során ad lehetőséget a katasztrófavédelmi akciókra. A különleges jogrendet megelőző, felkészülést segítő szervek is igen szerteágazóak, aminek a célja szintén az, hogy az alkalmazás előtt a kormány minden rendes eszközt kimerítsen a probléma kezelésére. Legfontosabb szerepe a kormánynak van, amely megalkotja a társadalmi biztonsági stratégiát, amely a legkomolyabb fenyegetéseket azonosítja be. A kormány mellett múködik a Külügyi és Biztonságpolitikai Miniszteri Bizottság, amely a legfontosabb nemzetbiztonsági szerv, elnöke a miniszterelnök, tagjai a miniszterek, üléseit pedig a köztársasági elnökkel közösen tartja. A miniszterelnök mellett múködő miniszterelnöki hivatal múködteti a Kormányzati Eseményközpontot, amely valós idejű módon követi a vészhelyzeti események kialakulását a nyilvános és az államapparátustól érkező információk alapján. Fontos szerep jut még a minisztériumoknak: a Belügyminisztérium az országot érintő veszélyek felmérése érdekében háromévente nemzeti kockázatelemzést készít, míg a Védelmi Minisztérium mellett mûkködő Biztonsági Bizottság az átfogó védelem kérdéseiben nyújt segítséget. A finn átfogó védelmi koncepció azt jelenti, hogy a vészhelyzetek elhárításában a társadalom egésze részt vállal.

Az alapjogok korlátozása kapcsán az alkotmány 23. szakasza az irányadó. Az alkotmány hiányossága, hogy nem határozza meg a korlátozhatatlan alapjogok listáját, ezt kizárólag a nemzetközi egyezményeknek való megfelelőség kritériumára bízva. Ez azért is különösen jelentős, mert az ország nem létezik elkülönült alkotmánybírósággal. A szakasz az országot érő támadás vagy bármilyen más komoly veszélyt jelentő vészhelyzet esetén teszi lehetôvé az alapjogok korlátozását. Az egyes különleges jogrendi törvényekben található esetkörök mellett bármilyen, ott nem nevesített korlátozásra is sor kerülhet, az alkotmány 23. szakasza alapján elfogadott törvény alapján.

A jelenlegi magyar szabályozással összehasonlítva elmondható, hogy a finn szabályozás mindössze két esetkörrel operál, szemben a magyar jogrendben található hat esetkörrel. A finn esetkörök nem különíthetők el egymástól élesen, sőt, a kapcsolódó törvények egyidejû́ alkalmazása sem kizárt, több elrendelési esetkör átfedést mutat egymással (például a fegyveres támadás). Ezzel szemben a magyar szabályozás esetén az egyes különleges jogrendi típusok tartalmi elemei élesen elkülönülnek egymástól. A finn szükségállapot a magyar hadiállapot mellett a veszélyhelyzet és több válsághelyzeti szabályozás jegyeit is magában foglalja, hiszen azt súlyos baleset, katasztrófa és fertőző betegség esetén is el lehet rendelni. Ráadásul a finn védelmi állapot sem feleltethetô meg a magyar rendkívüli állapotnak, hiszen előbbi magában foglalja a magyar szükségállapot alatt szabályozott alkotmányos rend megváltoztatására irányuló erőszakos fellépést. Az Alaptörvény kilencedik módosítása alapján a két szabályozás nem sokban közeledik egymáshoz. Ugyan a magyar szabályozásban is összeolvad több különleges jogrendi jogintézmény, és csak a hadiállapot, a szükségállapot, 
valamint a veszélyhelyzet marad, a két jogrend esetköreit még így is nehéz összehasonlítani egymással. A finn szükségállapot például továbbra is részben a magyar hadiállapot (külső fegyveres támadás), valamint a veszélyhelyzet jegyeit is magán viseli majd.

Az elrendelés kapcsán is éles eltérés mutatkozik: idehaza esetkörtől függően az Országgyúlés (szükség-, illetve hadiállapot) vagy a Kormány (veszélyhelyzet) jogosult azok elrendelésére, míg a finn szabályozásban a szükségállapotot a kormány és a köztársasági elnök, addig a hadiállapotot a köztársasági elnök rendeli el. Míg idehaza erős a parlamenti kontroll az elrendelés kapcsán, addig a finneknél semmilyen parlamenti hozzájárulás nem szükséges a különleges jogrend bevezetéséhez. Kizárólag az egyes végrehajtási rendeletek esetén van szükség a törvényhozás utólagos jóváhagyására. Ez a fajta megoldás a magyar veszélyhelyzet jelenlegi szabályozásához hasonlítható, ám nem teljes egészében, különösen az Alaptörvény kilencedik módosítása szerinti új szabályozás alapján nem, amely utóbbi értelmében hazánkban magát a veszélyhelyzetet kell meghosszabbítani a határidőn túl, nem pedig az egyes veszélyhelyzeti kormányrendeletek hatályát. A két határidő egyébként lényegesen eltér: míg idehaza 15 nap, Finnországban 3-6 hónap. Bár az eltérések kétségkívül jelentősek, mégsem mondható, hogy a finneknél alacsonyabb lenne a különleges jogrend esetén a kormány feletti országgyúlési kontroll, mint idehaza. Ennek oka az, hogy a különleges jogrend ugyan formailag elrendelhetô a törvényhozás hozzájárulása nélkül, tényleges tartalommal csak annak hozzájárulásával tölthetô ki.

Mindezek alapján elmondható, hogy a magyar és finn szabályozás nehezen hasonlítható össze, ugyanis lényegesen eltérő rendszerben gondolkodnak. A finneknél bizonyos szempontból nagyobb hangsúly jut a törvényhozásnak a különleges jogrend során - amely esetén még utalás sem történik arra az esetre, ha a parlament nem tud ülésezni és elvégezni a kontrollt a végrehajtási rendeletek felett -, ami alkotmányos szempontból biztosabb, ám csökkenti annak hatékonyságát. Ugyanakkor más szempontból jóval kisebb a törvényhozás szerepe, hiszen ott a parlament nem szólhat bele a különleges jogrend elrendelésébe, csak annak szabályai kapcsán gyakorol kontrollt. Jelentős eltérés mutatkozik nemcsak az egyes különleges jogrendi esetkörök terén, de abban is, hogy mit tekint az adott jogrendszer a különleges jogrend részének. A finn rendszer ugyanakkor számos problémával küzd, így például azzal, hogy a szükségállapoti szabályozást tartalmazó törvény nehezen illeszthető be az alkotmányos rendbe, annak szerkezete pedig túlságosan is szerteágazó és bonyolult. Ráadásul a különleges jogrendi törvények mellett az alkotmány 23. cikke alapján is lehet alapjog-korlátozó intézkedéseket hozni. Mindezek alapján kijelenthető, hogy a magyar szabályozás - különösen a kilencedik Alaptörvény-módosítást követően - sokkal gördülékenyebb és jobban beágyazott a jogrendszerbe. 


\section{Irodalomjegyzék}

Cornell, A. J., SAlminen, J. (2018) 'Emergency Laws in Comparative Constitutional Law The Case of Sweden and Finland", German Law Journal, 19(2), 219-250. 0.

Grogan, J. (2020) States of Emergency [Online]. Elérhető: https://verfassungsblog.de/states-ofemergency/ (Letöltve: 2020. december 15.)

HusA, J. (2011) The Constitution of Finland: A Contextual Analysis. Oxford-Portland: Hart Publishing

KHAKEE, A. (2009) Securing Democracy? A Comparative Analysis of Emergency Powers in Europe [Online]. Elérhető: www.files.ethz.ch/isn/99550/PP30_Anna_Khakee_Emergency_ Powers.pdf (Letöltve: 2020. december 15.)

Makarychev, A., Romashko, T. (2021) 'Precarious Sovereignty in a Post-liberal Europe: The COVID-19 Emergency in Estonia and Finland', Chinese Political Science Review, 6(1), 63-85. o.

MoIsio, S. (2020) 'State Power and the COVID-19 Pandemic: The Case of Finland', Eurasian Geography and Economics, (61)4-5, 598-605. o.

Neuvonen, P. J. (2020) 'The COVID-19 Policymaking under the Auspices of Parliamentary Constitutional Review: The Case of Finland and Its Implications', European Policy Analysis, 6(2), 226-237. 0.

OJANEN, T. (2007) 'EU Law and the Response of the Constitutional Law Committee of the Finnish Parliament' in Wahlgren, P. (szerk.) Scandinavian Studies in Law. Stockholm: Stockholm University Law Faculty

Penttila, R. (1991) Finland's Search for Security through Defence, 1944-89. New York: Palgrave Macmillan

SAlminen, J. (2020) 'Finsk krishantering i fredstid - beredskapslagen tillämpas för första gången', Svensk Juristtidning, 105(10), 1116-1129. o.

SAlONIUS-PASTERNAK, C. (2019) 'Finland's amibigiuous deterrence' in Vanaga, N., Rostoks, T. (szerk.) Deterring Russia in Europe: Defence Strategies for Neighbouring States. New York: Routledge

Scheinin, M. (2020) The COVID-19 Emergency in Finland: Best Practice and Problems [Online]. Elérhető: https://verfassungsblog.de/the-Covid-19-emergency-in-finland-best-practiceand-problems/ (Letöltve: 2020. december 15.)

Tiirinki, H., Tynkkynen, L-K., Sovala, M., Atkins, S., Koivusalo, M., Rautiainen, P., Jormanainen, V., Keskimäki, I. (2020) 'COVID-19 Pandemic in Finland - Preliminary Analysis on Health System Response and Economic Consequences', Health Policy and Technology, 9(4), 649-662. o.

Vanaga, N., Rostoks, T. (2018) Deterring Russia in Europe: Defence Strategies for Neighbouring States. 1. kiadás. New York: Routledge 